\title{
Human Rights Impacts of Development Induced Displacement in Addis Ababa: The Case Study of Kirkos Sub City Woreda 11
}

\author{
Negera Gudeta Adula \\ Lecturer at Mettu University and PhD Candidate in Global and Area Studies \\ at Addis Ababa University, Institute for Peace and Security Studies
}

\begin{abstract}
Development induced displacement is an ever rising global phenomena which displaced people from their homes, home lands and place of usual residence. This study examines human rights impacts of development-induced displacement in Addis Ababa, kirkos sub city woreda 11. The study employed qualitative research approach. Data was collected from both primary and secondary sources. A primary source of data was collected through key informant in-depth interview and observation. A purposive and snowballing sampling technique was employed to select informants from target population. The secondary source of data was collected from books, journal articles, government reports, newspaper and published and unpublished materials to substantiate the data collected from primary sources. The finding of the study revealed that development-induced displacement amounted to the violation of human rights of displaced persons because the displaced people weren't compensated and remedied adequately, and consulted and participated in the development project. Moreover, the study also uncovered that people have evicted arbitrarily from their homes without due process of law and the majority of displaced people have not yet access to social services for their human wellbeing after resettlement. The finding of the study suggested that, the displaced people by development project should be informed before displacement, participate and contributed to the development project which displaced them. The displaced people should compensated and remedied adequately and take rehabilitation assistances after their resettlement.
\end{abstract}

Keywords: Development-induced displacement, human rights, Addis Ababa, kirkos sub city

DOI: $10.7176 / \mathrm{JCSD} / 64-02$

Publication date:May $31^{\text {st }} 2021$

\section{INTRODUCTION}

Economic growth believed to be the most powerful instrument to address poverty and improve the living standards of the people. This assumption is promoted by both national governments and multilateral institutions such as United Nations Organizations. Since the creation of UN, economic development became the prior objective for United Nations system and international communities. Developing countries including Ethiopia put poverty reduction and economic development at top of their national policy (IDMC, 2017). The September 2000 New York Summit which hosted a large number of heads of state and governments set a base for the foundation of Millennium Development Goals (MDGs) of which economic development and poverty eradication was a prior agenda (Jonsson, 2003).

It was to this end that, the world nation states and developing countries have begun to undertake different large-scale development projects such as irrigation schemes, dam constructions, natural resource extraction, construction of roads, creation of industrial and national parks, expansion of agricultural investment, urban expansions, urban renewal programme and slum clearances which serve as the vehicles for development. However, it amounted to not only displacement and upheaval of people from their homes, homelands, and place of their usual residence but also lead to grave humanitarian and human rights crisis especially in the developing countries (Shivani, 2010).

In contrary to this, Human Rights and development became also twin central themes and indivisible pillars of United Nations system since its creation which followed by the adoption of Universal Declaration of Human Rights which again ushered new era for international commitment in the realization of human rights and fundamental freedoms in addition to collective responsibility to improve the living standards of people and maintaining international peace and security, but scant attention was given to the interdependence and mutual reinforcement of human rights and development (Hamm, 2001).

Unlike other forms of internal displacement such as conflict induced displacement and natural disaster induced displacement which has been existed from the time of antiquity, development induced displacement is the youngest category of internal displacement. After the colonial period, dam construction is taken as a symbol of independence, the symptom of economic development and the only viable means to satiate the growing energy needs in developing world caused displacement of a large number of people from their homes and place of usual residence (Terminski, 2012).

In the context of Africa, the rapid population growth with growing the needs for energy especially in the mid-20th century forced post-colonial African leaders to come up with the idea that undertaking development projects such as dam constructions, for generating electricity can improve the quality of life and meet the 
growing needs for energy. It was to that end that, Aswan dam was constructed by Nasser government between 1958-1971 in Egypt and resulted in displacement of 100,000-120,000 Namibians, the Akosombo dam constructed between 1961-1965 in Ghana and amounted to upheaval of 80,000 peoples from their homes and homeland and Kariba Dam was constructed between 1950-1955 and uprooted about 57,000 people from their homes, home lands, and place of their habitual residences (Terminski, 2013; Stanley, 2004).

In the context of Ethiopia, unlike other types of internal displacement, development induced displacement is the recent phenomenon, the construction of dams such as Koka dam construction which began in 1957 during imperial regime and Gilgel Gibe I construction which begun 1984, for energy generation and state farms during the Derg regime were viable historical large scale development projects which resulted in the displacement of the people from their homes and place of habitual residence. The downfall of the military regime in 1991 escorted new era in terms of infrastructural developments which undertaken to ensure public wellbeing and improve living standard of the people because EPRDF regime considered poverty as existential threats to the state and its people, however undertaking development projects lead to displacement and upheaval of a large number of people from their homes and often homelands (Messay and Bekure, 2011 as cited in Endeshaw, 2016; Fana, 2016).

EPRDF government portrayed poverty reduction and economic development as the alpha and omega for the national survival of the country and poverty and underdevelopment identified as an existential threat to the country (Asnake, 2011). Beside this, EPRDF regime considered economic development as an important tool of legitimacy construction for the party especially since 2000 and everything else is secondary and comes after economic development (Fana, 2016).

It was to this end that, government undertakes different development projects such as large scale agricultural investments, road, highway and railway construction, urban renewal projects, construction of industrial parks, national parks construction, urban expansions, dam construction and irrigation schemes, water reservoir and canals, and wildlife conservations. However, though these development projects are undertaken for the purposes of wellbeing and welfare of the public at large, it made some section of the society to shoulder the costs and pain of these development projects because it leads to displacement of people from their usual habituation (Kassa, 2015; Azeb, 2017).

Moreover, the adoption of developmental state model of growth which aimed to bring a structural change and transformation of the economy through rapid industrialization and modernization under the slogan "we will make poverty history" by EPRDF government in early 2000's in which lion role is played by the state made undertaking large scale development project permanent development programme in Ethiopia however, the development induced displacement adversely affected the livelihoods of the displaced people (Abis, 2014).

Addis Ababa, the capital city of Ethiopia has begun undertaking major transformation especially since 1991 which evidenced by construction of road networks, such as railways and highways schools, healthcare institutions, condominiums, real estates, banks, shopping centers, urban renewal programme and slum clearance which serve as a fuel for development by making the city better place to live and attracting both foreign and domestic investor which create job opportunity for citizen but what remain hidden and unnoticed is the impacts of these development projects on the lives and livelihoods of displaced people (Gebre Y., 2008; Tibarek, 2013).

Thus, though extensive works were undertaken on the impacts of development induced displacement in Ethiopia, human rights impacts of development induced displacement is list documented and inadequately studied in Ethiopia in general and Addis Ababa in particular. Thus, the main objective of this study is to examine human rights impacts of development induced displacement under three phases of displacement (pre, during and post) displacement phases and scrutinize the nexus between human rights and development. To achieve the intended objective, this study employed qualitative research approach. Data was collected from both primary and secondary sources. Primary sources of data were collected through key informant in-depth interview and observation. Purposive and snowballing sampling techniques were employed to select informants from target population. The secondary source of data was collected from books, journal articles, government reports, newspaper and published and unpublished materials to substantiate the data collected from primary sources. The date collected from both primary and secondary sources were also analyzed qualitatively.

\section{RESULT AND DISCUSSION}

\section{PRIOR TO DISPLACEMENT HUMAN RIGHTS IMPACTS OF DEVELOPMENT INDUCED DISPLACEMENT}

\subsection{PARTICIPATION, AND CONSULTATION RIGHTS}

People displaced by development projects have human rights to participation and consultation by government officials prior to their displacement from their homes and place of usual residence. Participation of people is the active involvement of persons in particular development project and the sensitization of people to increase their receptivity and ability to respond to development projects (Sibanda, 2011). The displaced people by development project have the right to participate in every step of development projects and to be consulted and 
informed by concerned officials before their displacement. FDRE Constitution Art. 43 (2) states that, every nation has right to participate in national development and has to be consulted with respect to policies and projects affecting their lives and livelihoods.

However, according to the views of my respondents the displaced people neglected participation and consultation rights prior to displacement; they were forced to leave their homes and habitual residences without having information on what kind of development project is going to be undertaken after they left their habitual residence. In the same vein research finding of Moges Gobena (2010) revealed that, large scale development projects including agricultural investment in Ethiopia, affects the life and livelihoods of local people because development project is undertaken in a very non-participatory way, the local community couldn't participate in the development projects, despite the existence of important policies, strategies, and proclamations that enable local people to take part in development projects and allow them to get their voice heard. large-scale development projects such as road, highway and railway constructions and urban renewal programs which undertaken in different sub-cities of Addis Ababa imposed costs on some section of society since they scarify their livelihoods, source of income, houses and the social capital because infrastructural developments are undertaken without participation, consultation and contribution of displaced people (Mudhin A., 2016).

\subsection{COMPENSATION AND PROPERTY RIGHTS}

The people displaced by development project should receive appropriate and adequate compensation for their property which destroyed due to development project because compensation restores the original living standards of the people (Patil and Ghosh, 2015). The goal of adequate compensation is to improve or at least restore material and non-material conditions reduced or lost as a result of displacement and to enable people to rebuild their mode of life again (Terminski, 2013). Council of Ministers Regulations No. 135/2007 on the payment of compensation for property situated on landholdings expropriated for public purposes stipulated that "an individuals or groups of people who displaced by development project have the rights to take appropriate and adequate compensation for destroyed properties and lost assets due to development projects and for transferring of properties".

The article 3 (1), 3(2) and 3(10) of Council of minster regulation No.135/2007 enshrined that "the amount of compensation for a building shall be determined on the basis of the current cost per square meter or unit for constructing a comparable building and the current cost for constructing floor tiles of the compound, septic tank and other structures attached to the building; and the owner of a building shall have the right to claim compensation for the entire building by surrounding the total land in his possession where part of the building is ordered to be removed and again the compensation for relocated property; the amount of compensation for a relocated property shall be determined by computing the estimated costs of labor, material, and transport to be incurred at market value for' removing; transferring and installing the property

Hence, as enshrined in the provision of council of minister's regulation No.135/2007, and other domestic and international norms, people displaced by development project have compensation and remedy rights prior to displacement phase for destroyed and lost assets and transferring properties to new resettlement site and national authorities and concerned stakeholder shoulder primary responsibility in ensuring the realization of remedy and compensation rights. But, the displaced people were forced to oust their home without receiving adequate and commensurate remedy for their property which destroyed due to development project.

However, this contradicts with FDRE constitution Art. 44 (2) which state that every displaced person by development project entitled to remedied and compensated for properties destroyed and adversely affected by development projects and have the right to commensurate monetary or alternative means of compensation. Large scale development projects such as railway and highway construction in Addis Ababa and Oromia special zone surrounding Addis Ababa negatively affects the livelihoods and life of displaced persons because of inadequate delayed and incommensurate compensation paid for displaced people (Bikila A., 2014). Simultaneously, Mehari Tadelle (2017) stated that, infrastructural development projects in Addis Ababa such urban renewal projects and expansion of agricultural development through large scale land acquisition in different regions of Ethiopia such as Gambella, Benishangul Gumuz, and Oromia, lead to different risks and impoverishments including income decline and joblessness due to the absence of adequate compensation and remedy package that supposed to paid for displaced people and this resulted in the advent of violent reaction, and compliance from the side of displaced persons.

Thus, violation of compensation and remedy rights of displaced people also leads to the violation of the property rights because displaced people deprived their movable and immovable property due to development projects. However, such action is illegal and contradicts with FDRE constitution Art. 40 (1) and 40 (2) which state that "every Ethiopian citizen has the right to ownership of private property which includes a tangible or intangible product which has value and is produced by the labor, creativity, enterprise or capital of an individual citizen". 


\section{DURING DISPLACEMENT HUMAN RIGHTS IMPACTS OF DEVELOPMENT INDUCED DISPLACEMENT}

\subsection{PROHIBITION OF ARBITRARY DISPLACEMENT, LIBERTY AND DIGNITY RIGHTS}

Displacement of people by development projects such as urban renewal should not be undertaken forcefully and arbitrarily. Arbitrary displacement due to development projects is a violation of human rights of internally displaced persons. Forceful and arbitrary eviction of people from their homes and place of their usual residence due to development projects constitute violation of human rights (Challa K., 2013, Kalin, 2010).

Article 6(1) of United Nations guiding principle on internally displaced persons enshrined prohibition of arbitrary displacement in cases of large scale development as human rights of development induced displaced persons during the time displacement phase and stated that "every human being shall have the right to protect against being arbitrarily displaced from his or her home or place of habitual residence (UNGP, 1998). Africa Union Convention for Protection and Assistance of Internally Displaced Persons in Africa again stipulated that "national authorities should refrain from displacing people arbitrarily and primarily responsible to prevent and prohibit arbitrary displacement people by any of causes of internal displacement.

But, one of my respondent stated that "woreda officials and woreda police didn't consider our human rights during displacement because they displaced us forcefully and arbitrarily. They demolished our properties and beat us while we refuse to go because of limited preparation time and lack of commensurate compensation. Besides that, they organized jobless woreda youth to take away steel sheets from our homes and the organized youth were taking away the steel sheets while we were in our homes; we suffered a lot during displacement to transfer our property; we scarified our dignity and liberty rights during the time of displacement.

The other respondent again added that, "the time of our displacement was on the eve of Easter; we have been fasting for two months, but they forced us to oust and leave our homes. We have prepared tela and other things for Easter holiday, but we displaced by watering down our tela (local beer made from barley and other ingredients for holiday) and leaving everything's that our wife's prepared for the holiday". The government of Ethiopia formulated a long term economic development strategy called Agriculture development led industrialization (ADLI) as a response to poverty, and food security challenges but it amounted to forcibly displacing hundreds of thousands of indigenous Peoples which resulted in other impoverishments and risks on the livelihoods of displaced people (Azeb, 2017).

Explaining the protection of their liberty and dignity rights during time of displacement my informants stated that "development project violated not only right to dignity and liberty but the right to life of displaced people indirectly. The elder women household head was passed away here after displacement due to stress which resulted from their forceful and arbitrary displacement. Development projects which include large scale land acquisition for investment (land grapping) and urban expansion in Ethiopia lead to a violation of human rights of displaced persons in different regions of the country and the government use forces to evict people from their homes, homelands, and place of their usual residence arbitrarily which include beating, intimidation and other mistreatments of a displaced person which is violation of dignity and liberty displaced persons (Malkamuu J. 2016).

\subsection{FREEDOM OF MOVEMENT AND RESIDENCE RIGHTS}

Freedom of movement and choosing once own residence is fundamental human rights and basic and precondition for enjoyment and exercise of other human rights. Freedom of movement and residence is closely related to liberty and security rights. Violation of freedom of movement resulted in different consequences such as limited access to social services, access to job, market and health and wellbeing of individuals.

Freedom of movement and choosing once own residence rights of internally displaced persons by development projects are protected and enshrined in both domestic and international norms. FDRE constitution stipulated that "any Ethiopian has the right to liberty of movement and freedom to choose his/her residence". Congruently, AU Convention for Protection and Assistance of internally displaced persons in Africa obliges the national authorities to guarantee the freedom of movement and choice of residence of internally displaced persons and UN guiding principle on internally displaced persons also enshrined that "every internally displaced person has a right to liberty of movement and freedom to choose his/her residence.

However, explaining their freedom of movement during time of displacement one of my respondent stated that "we left our homes and places of usual residence forcefully within three days only and we didn't given any alternative to choose our own residence, they randomly resettled us". Thus, the development project violated our freedom of movement and choosing our own residence. Congruently Vanclay and Ploeg (2017) stated that expropriation and involuntary resettlement due to development projects are contrary to fundamental human rights such as the right to freedom of movement, choice of residence and right to housing. Thus, development project violates freedom of movement and residence rights because it involves arbitrary eviction of people from their homes and places of usual residence. In the same way, Mehari, (2011) stated that development induced displacement negates the most fundamental human rights during a time of displacement including freedom of 
movement and residence of the displaced people because development induced displacement involves forceful eviction of people from their habituation.

\section{POST-DISPLACEMENT HUMAN RIGHTS IMPACTS OF DEVELOPMENT INDUCED DISPLACEMENT}

\subsection{ACCESS TO SOCIAL SERVICES RIGHTS}

After displacement the displaced people have human rights to have access to social services such school health care institutions, water supply and electricity like other nationals. An internally displaced person has rights to have access to different social services such as health service and sanitation, school, potable water, and electricity and national authorities are primarily liable to allocate these facilities before displacing. FDRE constitution, Art. 41 (3) and 41 (4) enshrined that "Ethiopian national has the right to equal access to publicly funded social services and the state has the obligation to allocate and provide public services such as public health, education and potable water and electricity".

Besides what is enshrined under FDRE constitution, AU Convention for Protection and Assistance of Internally Displaced Persons in Africa and United Nations guiding principles on internally displaced persons also stipulated access to social services rights of displaced persons by development projects. Article 23 (1) of United Nations guiding principle on internally displaced persons stated that "displaced persons have right to get an education and ensuring the access of public school is the primary responsibility of national authorities".

Regarding their access to social services after displacement one my informant stated that "before we left our homes and place of our usual residence, the woreda officials promised us a lot about our accessibility to social services but there is inadequate social services after we came here. For instance, in terms of public school, before coming here our children were attending public school, after displacement our students are attending private school due to lack of nearby public school. There is only one public primary school which is too far from us and hosts more than 86 students in the single classroom.

Inner city housing and urban development induced displacement in Addis Ababa made displaced people shoulder different coast and risks such as lack of access to social service facilities like school, health service, and sanitation electricity shortage and unavailability of potable water, poor housing condition, unaffordability of condominium house, loss livelihoods and basic assets and increase of the level of poverty (Tibarek L, 2013). urban development and displacement in Addis Ababa leads to different impoverishments such as inaccessibility to basic social services such as water and healthcare institutions, sanitation and educations and dismantle and disruption of informal social networks (Gebre, 2008; Mehari, 2017).

\subsection{DEVELOPMENT, LIVELIHOODS AND SELF-DETERMINATION RIGHTS}

In addition to access to social services rights, displaced persons have human rights to development which include the right to earn income to sustain and improve their lives, livelihoods, and employment rights. Human rights to development are third generation rights which refer to an inalienable human right by virtue of which every human person and people entitled and it includes the economic, cultural, social and political development of human persons as a single member of entire people. FDRE constitution article 43 (1) state that "the peoples of Ethiopia as a whole, and each nation, nationalities, and people, have human rights to development which include right to improve once own living standards". Article 41 (1) state that "every Ethiopian has the right to engage freely in economic activities, pursue his/her livelihoods and choose his or her means of livelihoods, occupation, and profession'.

Regarding their income after displacement period one of my informant stated that "I am widow women, I do have 12 children. Before coming here, I was in the center of the city, I was a shopkeeper and I was having daily income from the shop, I do have many customers there. Besides that, I was also preparing injera and selling it there, but today thinking like that is dream, as you see I am selling onion, potato, and tomatoes on the strait side, I don't have customer here, beside this we are also forced to leave even this place by woreda police, in the future, I don't know what will happen to me and my children's". Urban infrastructural developments such construction railway deteriorates the livelihoods of the displaced people in Addis Ababa and Oromia special zone surrounding Addis Ababa because it leads to joblessness and unemployment which is resulted from the reduction of income sources due to resettlement to the new site (, Bikila A., 2014). However, this contradict with FDRE constitutions Article 41 (6) and 41(7) state that "the national authorities shall undertake all measures necessary to increase job opportunities for citizens to find gainful employment and pursue policies to expand job opportunities for all nations, nationalities, and people in general and unemployed and the poor sections of the society in particular.

\subsection{REHABILITATION RIGHTS}

Rehabilitation assistance is the viable way to reconstruct of demolished social and economic life of the displaced people by development project (Hathi, 1990). Displaced Persons have human rights to receive rehabilitation 
assistance to rehabilitate their life and livelihoods after displacement. Cernea (2000) stated that those displaced people by development projects are supposed to receive compensation for their lost assets and effective assistance to re-establish themselves productively. According to United Nations guiding principle on internally displaced person, Article 25 (1) the primary duty and responsibility to provide rehabilitation assistance for internally displaced persons by development projects and other of internal displacement lies on national authorities. FDRE constitution Article 44 (2) also stated that all persons who have been displaced and whose livelihoods are affected by development projects have rights to receive adequate rehabilitation assistance and the state shoulder primary responsibility to provide rehabilitation assistance for people whose life and livelihood affected by development project undertaken either by public or private sector for public purposes. Moreover, Expropriation of Landholdings for Public Purposes and Payment of Compensation Proclamation No. 455/2005 also stipulated that national authorities are responsible not only to pay compensation but also to assist displaced persons to restore their livelihoods by offering rehabilitation assistance. With regard to this one of my respondent stated that, from the very beginning the development project was not people-centered development, let alone having the rehabilitation assistance we didn't paid adequate and fair compensation for our properties and assets which aggravate and exacerbate our problem in addition to lack of employment opportunity and income sources after displacement.

Thus, despite the presence of both domestic and international norms which protected and stipulated rehabilitation assistance rights of displaced persons after resettlement to reconstruct their life and livelihoods which destroyed by development project and obliged the national authorities to provide rehabilitation assistance, the people displaced by development project from Addis Ababa kirkos sub city woreda 11 didn't receive rehabilitation assistance. Therefore, the development project in Addis Ababa, kirkos sub city woreda 11, violated not only the participation, consultation, compensation, development and self-determination rights of a displaced person but also the rehabilitation assistance rights of displaced people which implies absence of commitment on the side of national authorities and concerned stakeholder to both domestic and international norms which protect and enshrined the human rights of displaced persons.

\section{CONCLUSION}

Development induced displacement is worldwide ever rising phenomenon that amounted not only to the upheaval and oust of a large number of people from their homes, homelands and often a place of usual residence but also leads to the grave violation of human rights and humanitarian crisis. This also holdstrue in the context of Ethiopia. In Ethiopia, poverty reduction and ensuring economic development became the prior policy of the country after demise Derg regime because EPRDF considered economic development the best tool of legitimacy construction for the party and portrays poverty and underdevelopment as existential threats to the state and its people. It is to this end that, EPRDF government is undertaking different infrastructural developments as means to realize economic transformation and ensure the countries' economic development. The adoption of developmental state growth model after 2005 also brought rapid infrastructural development in the country in general and Addis Ababa in particular but these infrastructural developments and large-scale development projects have adverse effects on the lives and livelihoods of displaced people including the violation of human rights and loss of income generation sources.

This study examines the human rights impacts of development induced a displacement in Addis Ababa, kirkos sub city woreda 11 at three different phases of displacement (pre- during and post) displacement phase. The finding of this study revealed that development induced displacement in kirkos sub city woreda 11 violated human rights of displaced persons both under pre-displacement phase, during actual displacement phase and post displacement phases.

With regard to prior to displacement phase, the finding of the study reveal that development induced displacement negates participation, consultation, compensation, property and contribution rights of a displaced persons. During the displacement phase, the finding of the study also revealed that development project lead to infringement of liberty and dignity rights, freedom of movement and residence rights. Moreover, with regarding post displacement phase finding of the study revealed that development induced displacement violated access to social services, rehabilitation development, livelihoods and self-determination rights of displaced persons.

Finally, the finding of this study revealed that, the nexus between human rights and development regarding development induced displacement is negative because development project was not people-centered development, the displaced people were not participated, consulted and contributed to development projects; human rights was not at center of development projects and human rights and development was not mutually reinforced.

\section{RECOMMENDATIONS}

The finding of this study revealed that development induced displacement in Addis Ababa kirkos sub city woreda 11, violated human rights of displaced persons. Taking proper measures is the only viable means to 
redress such negative impacts of development induced displacement and avoid the incidence of the same problem in the future.

Therefore, based on the finding of the study the following recommendations are forwarded to the concerned body and stakeholders to minimize the human rights impacts of development induced displacement and realize people-centered development in the future.

The people displaced by development project should participate, consulted and get informed about the development project prior to displacement and adequate and commensurate compensation for destroyed assets and transferring properties should be paid for people displaced by development project prior to displacement.

All feasible alternatives should be explored prior to displacement to avoid displacement of people. All possible alternatives should be explored by concerned national authorities before displacement to avoid displacement and the displacement by development project should be the last resort after all possible options explored and prior eviction impact assessment on human rights and socio-economic impacts of development project should be undertaken.

There should be involvement third party to monitor and observe the displacement process during the time of displacement to avoid the arbitrary displacement of people from place of their habitual residence and the displaced persons should have to access to basic social services and facilities in the resettled site. They should provide basic social services including potable water, electricity, school, health services and sanitation after displacement.

\section{References}

Abis Getachew (2014). The Paradox of Democratic and Developmental State in Ethiopia

African Union Convention for the protection and assistance of internally displaced persons in Africa/Kampala Convention (2009)

Azeb, Degife. (2017). the intricacies of large scale agricultural investment in Gambella Region, Ethiopia. Paper prepared for presentation at the World Bank conference on land and poverty. The World Bank Washington DC.

Bikila, Ayele. (2014). The Impacts of Development-Induced Displacement and Relocation on the Livelihoods of Households in Dukem area. Addis Ababa University Unpublished MA thesis.

Cernea, Michael. (2000). Risks and reconstruction: Experiences of resettles and refugees. World Bank Publications.

Challa, K. (2013). Development induced displacement; legal and Human Rights Perspectives. Bharati Law Review.

Endashaw, Gebre. (2016). Impacts of urban renewal displacement and resettlement on the economic and social life of displaced people; The case of yeka Ayat 2 condominium, Addis Ababa, Ethiopia. AAU unpublished thesis.

Fana, Gebresenbet. (2016). Land Acquisitions, the Politics of Dispossession, and State-Remaking in Gambella, Western Ethiopia. GIGA German Institute of Global and Area Studies.

Federal Negarit Gazeta. (1995). the Constitution of the Federal Democratic Republic of Ethiopia. Addis Ababa.

Federal Negarit Gazeta. (2005). Proclamation No. 455/2005 Expropriation of Landholdings for Public Purposes and Payment of Compensation Proclamation.

Gebre, Yintiso. (2008). urban development and displacement in Addis Ababa: The impact of resettlement projects on low-income households. Eastern Africa Social Science Research Review, 24(2), pp.53-77.

Hamm, B. (2001). A Human Rights Approach to Development. Human Rights Quarterly, 23 (4) pp. 1005-1031.

Hathi, A. (1990). Rehabilitation and Resettlement of Displaced Persons. Vikalpa, 15(1), 47-52.

IDMC. (2017). New displacements by conflict and disasters in 2016 Global Report on Internal displacement. Norwegian Refugee Council.

Jonsson, Urban. (2003). Human rights approach to development programming. United Nations Publications

Kassa, Teshager. (2015). Resettlement and sustainable livelihoods in Ethiopia: a comparative analysis of Amhara and southern regions, University of South Africa, Pretoria

Malkamuu Jaate. (2016). Land Grabbing and Violations of Human Rights in Ethiopia

Mehari, Tadelle. (2011). The Kampala convention and its contribution in filling the Protection gap in international law. Journal of Internal Displacement, 1(1), pp.91-130.

Mehari, Tadelle. (2017). Causes, Dynamics, and Consequences of Internal Displacement in Ethiopia. Working Paper Division Global Issues Stiftung, Wissenschaft and Politik German Institute for International and Security Affairs.

Moges, Gobena. (2010). Effects of large-scale land acquisition in rural Ethiopia: The case of Bako-Tibe Woreda, Swedish University of Agricultural Sciences, Uppsala, Sweden.

Muhidin Aman. (2016). Development Induced Displacement in the Context of Un Guiding Principles and AU Convention: Experience from Addis Ababa City Urban Renewal Projects unpublished MA thesis 
Patil, Vikram and Ranjan Ghosh. (2015). December. Farmer Displacement and Marginalization: A Transaction Cost Explanation from an Irrigation Project in India. International Association of Agricultural Economists. Milan, Italy.

Shivani, Chaudhry. (2010). "Development-induced Displacement and Forced Evictions" In Incorporating the Guiding Principles on Internal Displacement into Domestic Law: Issues and Challenges. Transnational Legal Policy, No. 41, pp: 625-626.

Sibanda, D. (2011). The role of community participation in development initiatives: the case of the danga ecological sanitation project in the Zvishavane district, Zimbabwe (Doctoral dissertation, University of the Western Cape).

Stanley, Jason. (2004). Development-induced Displacement and Resettlement, Forced Migration Online Research Guide, Refugee Studies Centre, University of Oxford.

Tebarek Leka. (2013). Inner City Housing and Urban Development-Induced Displacement: Impact on Poor Female-Headed Households in Arada Sub City of Addis Ababa, Ethiopia. Journal of Sustainable Development in Africa, (15)2, pp.131-141.

Terminski, Bogumil. (2012). Mining-induced displacement and resettlement: social problem and human rights issue (a global perspective), np.

Terminski, Bogumil. (2013). Development-induced displacement and resettlement: social problem and human rights issue. Geneva, Switzerland.

United Nations Guiding Principle on Internally Displaced Persons (1998)

Van der Ploeg, L., \& Vanclay, F. (2017). A human rights-based approach to project induced displacement and resettlement. Impact assessment and project appraisal, 35(1), 34-52. 